\title{
The Effect of Business Strategy and Management Control Systems Misfit On Hotel Performance
}

\author{
I Made Pradana Adiputra ${ }^{1}$, Lindawati Gani ${ }^{2}$ and Hilda Rossieta ${ }^{3}$ \\ ${ }^{1}$ Faculty of Economic, Ganesha University of Education (Undiksha) \\ Jl. Udayana 11, Kampus Tengah, Singaraja, Bali, Indonesia \\ ${ }^{2.3}$ Faculty of Economic and Business, University of Indonesia \\ Jl. Prof. DR. Sumitro Djojohadikusumo, Kukusan, Kecamatan Beji, Depok, Indonesia
}

DOI: http://dx.doi.org/10.15294/jda.v12i1.22753

Submitted: December 31 ${ }^{\text {th }}, 2019$ Revised: March 01 ${ }^{\text {th }}, 2020$ Accepted: March 04 ${ }^{\text {th }}, 2020$ Published: March $31^{\text {th }}, 2020$

\begin{abstract}
The purpose of this research is to test the level of misfit business strategy with management control system will negatively associate to company performance. This study contributes to the existence of an empirical test of the existence of the concept of business strategy misfit with the management control system will negatively associate the company performance based on contingency-fit approach. In addition, the results of this study are expected to be a consideration for managers in the service industry to consider contingency factors in organizational design to improve company performance. The research was conducted by survey method (questionnaire) and purposive sampling at 227 star hotels industry type in Bali which sourced from Tourism Office of Bali Province 2018. Research respondents are senior managers with a minimum 1 year working period and have comprehensive information on company policies and operations. Using statistical method of regression with residual approach (bivariate analysis), the result of research indicate that the result of research show according to hypothesis in research that the misfit between business and MCS has negative relationships with financial performance and non- financial performance in hotel industry in Bali.
\end{abstract}

Keywords: management control systems, business strategy, hotel performance

\section{How to cite (APA 6th Style)}

Adiputra, I., Gani, L., \& Rossieta, H. (2020). The Effect of Business Strategy and Management Control Systems Misfit On Hotel Performance. Jurnal Dinamika Akuntansi, 12(1), 14-23. doi:https:// doi.org/10.15294/jda.v12i1.22753

\section{INTRODUCTION}

The Management Control System (MCS) has two main activities namely planning or formulating strategies and controlling tasks performed by each level of management at the organization. The MCS framework that comprehensively shows the representation of aspects of core values, behavior, supervision and feedback is the levers of control (LoC) proposed by Simons. The role of MCS has an impact on the realization of the effectiveness of organizational control, especially in the scope of the LoC in the context of corporate risk, namely beliefs control provides basic values, goals, and direction for the organization, boundary control communicates the risks that must be avoided. Diagnostic controls monitor organizational results and correct deviations from performance standards and interactive controls that communicate information author $(\bowtie)$ E-mail: adiputra@undiksha.ac.id 
between superiors and subordinates (Simons, 2014).

LoC is a strategic management tool and theoretical framework for understanding its relationship to the context of control in organizations. Simons (2014) argues that the success of the company in implementing the strategy must be done by management by understanding the four main strategic variables, namely: core values, uncertainty, risks to be avoided and performance variables contained in each LoC. Strategy, uncertainty, risk, performance are interrelated and support one another. Widener (2007) focuses on aspects of the strategic uncertainty faced by a company that dominates its influence on the LoC so that it will find out its impact on the company's performance. Meanwhile, Fauzi et al. (2011) considers that environmental uncertainty along with other contingent factors has an influence on firm performance. Some MCS studies that use the LoC Simons framework include proving that diagnostic and interactive control will affect performance through corporate empowerment (Henri, 2006). Research Widener (2007) implements the understanding of MCS in his research framework that LoC is related to strategic uncertainty and strategic risk that will determine company performance. Fauzi et al. (2011) prove the role of several contingent factors with MCS on performance, Belief, boundary, diagnostic and interactive control have a role on corporate strategy and performance (Arjaliès \& Mundy, 2013; Rossing, 2013), corporate budgeting (Frow et al., 2010), the dynamics of company capability through a combination of LoC (Mundy, 2010), corporate innovation (Revellino \& Mouritsen, 2009) and the role of corporate culture on beliefs control and LoC interdependence (Heinicke et al., 2016). Bedford (2015) believes that the role of individual and complementary LoCs will support companies in innovating. Meanwhile the results of the summary of Martyn et al. (2016) conducted a meta-analysis of several MCS studies using the LoC framework based on a quantitative approach showing that the results of the study tended to provide an understanding of the antecedents, performance and results of using only diagnostic and interactive control. Research Speklé et al. (2017) provide empirical evidence related to LoC as a driver of organizational success that is explained that the intensity of the use of LoC is positively related to corporate empowerment and creativity. Adiputra et al. (2019) found that business uncertainty and LoC affect hotel performance.

Meanwhile in several studies prove the role of MCS (non-LoC) in the company. MCS will reduce opportunistic behavior and moral hazard as well as additional findings that corporate culture has a role in the choice of the MCS model (Van Der Meer-Kooistra \& Vosselman (2000). (Gani and Jermias (2012) examine the role of MCS in moderating the relationship of business strategy to bank performance in Indonesia. Using misfit analysis of business strategy and MCS shows the influence of both of them on bank performance. The conclusions from several MCS studies (both LoC and non-LoC) prove their role in organizational performance.

This study uses business strategy as a contingency variable. The reason for using these contingency variables is that the strategy has a close relationship with MCS. The choice of an organization's business strategy requires a fit with the MCS of the organization that has an impact on the performance of the organization (Gani \& Jermias, 2012). Strategies are also used as contingency variables on MSS and performance in various types of industries both manufacturing and services (Gani and Jermias, 2012; Putri, 2014; Desmiyawati and Azlina, 2013). Desarbo et al. (2005) even states that each market, industry, and local environment needs to suit the choice of business strategic orientation so that the implementation or strategic action taken can run effectively.

Research on management control systems is still not widely done in service companies such as hotels, except for those conducted by Adiputra et al. (2019). Hotels are service companies that tend to have unique characteristics and are different from other service companies such as banks. If banks have characteristics that are very bound by strict regulations, especially hotels in tourism areas such as Bali, are more likely to follow regulations issued by local tourism agencies or authorities or regional governments. This is a further study as in the research of Adiputra et al. (2019) which analyzes the fit between business strategy and management control systems on hotel 
financial and non-financial performance, which is different from previous studies of management control systems that do not use levers of control measurements such as Gani \& Jermias (2012) and the use of a sample of non-service companies such as Putri 2014) and Desmiyawati \& Azlina (2013). Likewise, the research of Fauzi et al. (2011) used the hotel industry in Central Java, but did not use the fit approach to analyze the suitability of contingency factors with management control systems. This is the novelty of this study for business strategies with a management control system based on the misfit approach and its effect on the financial and non-financial performance of hotels.

Research conducted by Gani and Jermias (2012) using a fit approach through the misfit between management control systems and business strategies influences company performance at banks in Indonesia. Misfit shows the deviation between the management control system variables and the strategy has negative implications on performance (Gani \& Jermias, 2012). The management literature and organizational science provide attention and interest in investigating an organization's ability to survive (Jermias \& Gani, 2005). Several studies have proposed that the contingent-fit between strategic orientation and contextual variables tends to have a positive relationship with performance as a trend of research in management accounting. The concept of fit has long been used in the management accounting literature to investigate the contingent relations between management accounting systems, contextual variables, and organizational performance (Riyanto, 2001). The concept of fit is still rarely used in the analysis of contingency approaches in accounting research.

Research that uses a fit with residual approach has not been done much in many management accounting studies. research conducted by Ja'far S \& Kartikasari (2008) investigated the effect of control systems on company performance by involving the role of environmental uncertainty perceived in BPR in Central Java. Using interaction and system approach with residual approach, which use to test of fit between contextual and organizational variables, tested the hypothesis. The result indicates that control systems affected to financial performance, which involved PEU and using system approach. Based on this research, the system approach is better than interaction approach. The residual approach is also used in the research of Gani \& Jermias (2012) which examines the misfit of business strategy and MCS on bank performance. The results of the study show that the misfit of business strategy and MCS has a negative effect on the performance of banks. Adiputra et al. (2019) which tests business uncertainty with MCS misfit on hotel performance. The results of the study show that the misfit of business uncertainty and MCS has a negative effect on the performance of hotels.

Research that examines business strategy, MCS and company performance was conducted by Tsamenyi et al. (2011) on companies in China using a survey proves that the choice of business strategy and MCS will determine the company's performance. The study uses linear regression and moderation testing with an interaction approach and has not analyzed the contingency-fit testing. Research that examines business strategy, MCS and company performance was conducted by Tsamenyi et al. (2011) on companies in China using a survey proves that the choice of business strategy and MCS will determine the company's performance.

A brief critical analysis in this case that in the era of globalization as it is today, business competition requires certain strategies by companies for going concern. The condition of the business environment must be considered by the company in this case by managers, so that it can anticipate any changes and dynamics of the environment together with the determination of the company's business strategy. This will relate to the company's MCS to regulate the behavior of members of the organization so that it is indicated that it will further complement and strengthen the organization's strategy for organizational performance. Some research on LoC focuses more on non-service companies (manufacturing and banks). Not many LOC studies have examined the service industry and used the misfit approach to follow the context of contingency fit according to contingency theory.

Drazin \& Van De Ven (1985) have identified that almost all accounting studies adopt a 
selection and interaction approach and an approach that has not been used in accounting research is residual analysis. This approach focuses on the lack of fit between contingent variables and system variables and is associated with organizational effectiveness. Duncan \& Moores (1989) explain that residual analysis examines the effect of deviations from several research models. In practice, the application of contingency theory tests the effect of deviation from the contextualstructural ideal model on performance. Lack of fit is the value of the deviation (residual) of the linear relationship between contextual and structural variables. Dewar \& Werbel (1979) stated four advantages of residual analysis. First, it can simultaneously test universalistic concepts and contingencies. Second, it provides the ability to generate several new ideas by simply comparing the correlation coefficient. Third, can overcome multicollinearity and fourth, residual analysis is able to produce the actual level of fit.

Several studies on LoC show the results that several contingent factors affect company performance (Fauzi et al., 2011), corporate strategy and performance (Arjaliès \& Mundy, 2013; Rossing, 2013), the dynamics of company capability through a combination of LoC (Mundy, 2010) and the role of corporate culture in the beliefs of control and interdependence of LoC (Heinicke et al., 2016), corporate innovation (Bedford, 2015). Martyn et al. (2016) prove that research on LoC tends to provide an understanding of antecedents, performance and results for the use of diagnostics and interactive control only. Speklé et al. (2017) prove LoC is positively related to corporate empowerment and creativity and hotel performance is influenced by misfit business uncertainty and LoC (Adiputra et al., 2019).

Research by Gani and Jermias (2012) on the effect of misfit strategy and MCS on financial and non-financial performance in 109 banking sectors in developing countries shows a negative relationship on strategy misfit and MCS on financial and non-financial performance on banks. Meanwhile, Fauzi et al. (2011) provide empirical evidence that hotel strategies are not related to management control systems and does not analyze its effect on the financial performance of the hotel. Following the research and based on contingency theory and contingency fit, the research hypothesis is:

H1: the degree of misfit between business strategy and management control systems will negatively affect the company's financial performance.

Research by Gani and Jermias (2012) on the effect of misfit strategy and MCS on financial and non-financial performance in 109 banking sectors in developing countries shows a negative relationship on strategy misfit and MSS on non-financial performance on banks. Fefer also to the research of Fauzi et al. (2011) found that the strategy of the hotel is not related to the management control system and does not analyze its effect on the non-financial performance of the hotel. Following the research and based on contingency theory and contingency fit, the research hypothesis is:

H2: the degree of misfit between business strategy and management control systems will negatively affect the company's non-financial performance.

\section{METHODS}

The population in this study is a star hotel in Bali. Using purposive sampling, one to five star classification hotels listed in the Bali Province Tourism Office database and the Bali Hotel and Restaurant Association in 2018 were 227 hotels. Research respondents are managers with a minimum tenure of one year and have complete and comprehensive information about company policies and operations. The form of this research is quantitative with the method of collecting data using primary data using a questionnaire and secondary data obtained from the company's annual report. Data were tested with SPSS and using residual regression techniques to answer hypotheses. residual regression testing stage is looking for misfit values based on the error value (residual) of the management control system regression equation on business strategies. The residual value is then calculated its absolute value to analyze the effect on hotel performance as 
shown in equations (2), (3) and (4).

Table 1. Measurement variables

\begin{tabular}{lll}
\hline \multicolumn{1}{c}{ Variable } & \multicolumn{1}{c}{ Explananation } & Measurement \\
\hline Business & defenders (6 items) & Likert 1-5 \\
Strategy & $\begin{array}{l}\text { prospectors (7 items) } \\
\text { analyzers (5 items) }\end{array}$ & \\
MCS & beliefs (4 items) & Likert 1-5 \\
& boundary (4 items) & \\
& diagnostic (4 items) & \\
& interactive (4 items) & Likert 1-5 \\
Hotel Performance: & financial (5 items) \\
& non Financial (5 items) & \\
\hline
\end{tabular}

Control variables include the total assets owned by five-star hotels presented in the 2018 annual report and the classification of five-star hotels with the criteria: $5=5$-star hotels; $4=4$ star hotel; $3=3$ star hotel; $2=2$ star hotel and $1=1$ star hotel.

Analysis of research data using a statistical regression method with a misfit approach with residual values adopted from Riyanto LS (2001) and used by Ja'far S and Kartikasari (2008), Gani and Jermias (2102) and Adiputra et al. (2019). The hypothesis testing formulation uses regression analysis, namely:

Business Strategy $=\alpha 0+\beta 1 \mathrm{MCS}+\mathrm{E}$

Meanwhile, testing the business strategy and MCS on financial and non-financial performance with asset control and star classification variables, namely:

Fin Performance $=\lambda 0+\lambda 1|\varepsilon i|+\lambda 2$ Asset $+\lambda 3$ Star Classification $+v$

Non-Fin Performance $=\lambda 0+\lambda 1|\varepsilon i|+\lambda 2$ Asset $+\lambda 3$ Star Classification $+v$

\section{RESULTS AND DISCUSSION}

The validity and reliability test of the research questionnaire was carried out before the data analysis to test the hypothesis. The test results show that the questionnaire meets the validity requirements and the questionnaire (untable). Therefore it is worth further data analysis. The research data was collected by sending 227 questionnaires via direct delivery via contact person to the hotel with a classification of 1 to 5 stars in Bali. This study began from the date of sending and collecting data for an effective period of 2 (two) months, from 1 October to 1 December 2018. A total of 181 general managers and managerial level participated to fill out the questionnaire. Eligible questionnaires were 181 questionnaires.

Descriptive statistics in this study include independent variables and dependent variables as shown in table 1 as below:

Table 2. Statsitic Descriptive

\begin{tabular}{|c|c|c|c|c|c|c|c|c|}
\hline \multirow[t]{2}{*}{ Variabel } & \multicolumn{2}{|c|}{$\begin{array}{l}\text { Defender } \\
(\mathrm{n}=78)\end{array}$} & \multicolumn{2}{|c|}{$\begin{array}{l}\text { Prospector } \\
(\mathrm{n}=63)\end{array}$} & \multicolumn{2}{|c|}{$\begin{array}{l}\text { Analyzer } \\
(\mathrm{n}=40)\end{array}$} & \multicolumn{2}{|c|}{$\begin{array}{l}\text { Total Sampel } \\
(\mathrm{n}=181)\end{array}$} \\
\hline & Mean & SD & Mean & SD & Mean & SD & Mean & SD \\
\hline \multicolumn{9}{|l|}{ Primary data } \\
\hline Fin Perf & 8.19 & 0.88 & 8.19 & 0.91 & 8.12 & 0.97 & 8.17 & 0.91 \\
\hline Non Fin Perf & 9.53 & 0.77 & 9.30 & 0.87 & 9.10 & 0.98 & 9.35 & 0.88 \\
\hline MCS & 78.71 & 6.62 & 77,72 & 6.32 & 75,25 & 6.12 & 77.53 & 6,23 \\
\hline \multicolumn{9}{|l|}{ Secondary data } \\
\hline Asset (millions) & 91527 & 17626 & 84036 & 12565 & 87795 & 16032 & 88095 & 15933 \\
\hline Star & 3.06 & 1.37 & 2.85 & 1.36 & 2.90 & 1.19 & 2.95 & 1.32 \\
\hline
\end{tabular}

Data source results from SPSS processing 2019 
Table 2 shows that respondents in the type of hotel business strategy showed MCS conditions through levers of control at a good level, high financial and non-financial performance standards, average total assets in each type of strategy in millions of rupiahs, and hotel classification three stars who participated more in research

Table 3. Regression Analysis the Effect of MCS on Business Strategy

\begin{tabular}{llll}
\hline Variabel & Defender & Prospector & Analyzer \\
\hline Intercept & $8.756^{* *}$ & $7.951^{* *}$ & $7.671^{* *}$ \\
Belief & $0.269^{* *}$ & $0.873^{* *}$ & $0.008^{* *}$ \\
Boundary & $0.031^{* *}$ & $0.373^{* *}$ & 0.109 \\
Diagnostic & $0.148^{* *}$ & 0.058 & $0.089^{* *}$ \\
Interactive & 0.035 & -0.118 & $0.135^{* *}$ \\
Adjusted Square & 0.201 & 0.368 & 0.193 \\
$\mathrm{~N}$ & 78 & 63 & 40 \\
\hline
\end{tabular}

Data source results from SPSS processing 2019

Based on table 3 shows that in each type of strategy both defender, prospector and analyzer put forward belief control. Meanwhile hotels that use a defender strategy put forward boundaries and diagnostic control in addition to belief control. Hotels with a prospector strategy prioritize boundary control in addition to belief control. Hotels with the strategy analyzer type put forward diagnostic and analyzer control in addition to belief control. The very low adjusted $r$ square value due to the MCS variable is analyzed its effect on each type of strategy so that it is likely to be the cause. In addition there are other factors that may be more influential

The next test is a business strategy misfit regression through absolute residuals obtained from the initial regression equation that will be regressed with the dependent variables namely financial performance and non-financial performance as well as asset control and star classification variables in hotels in tables 4 and 5.

Tabel 4. Misfit Regression

Financial Performance $=\lambda 0+\lambda 1|\varepsilon i|+\lambda 2$ Asset $+\lambda 3$ Star Classification

\begin{tabular}{lc}
\hline Description & Coefficient \\
\hline Intercept & $9.785^{* *}$ \\
Misfit & $-0.377^{* *}$ \\
Asset & $4.248^{* *}$ \\
Star & -0.038 \\
Adjusted $R^{2}$ & 0.29 \\
$\mathrm{~N}$ & 181 \\
\hline
\end{tabular}

Data source results from SPSS processing 2019

Based on table 4 above shows that the misfit variable is negative and significant, meaning that there is a misfit of business strategies for both defenders, prospectors and analyzers and MCS has a negative effect on financial performance at a significance of 0.05 . The test results support the $\mathrm{H} 1$ hypothesis of this study. This shows that any form of business strategy choices in the company will be related to MCS so that it will affect the company's financial performance. In this case the misfit approach in this study proves that the existence of a small discrepancy between the business strategy and MCS will have a significant negative effect on financial performance, meaning that the form of suitability of the business strategy and MCS becomes absolute to determine better financial performance. The very low adjusted $r$ square value is due to the effect of analysis of the residual value which is absolute from the misfit of business strategy and MCS. In addition there are other factors that may further affect financial performance. 
These results are in line with the research of Tsamenyi et al. (2011) that the choice of business strategy and MCS will determine the performance of the company as well as Gani and Jermias (2012). The choice of a defender and prospector strategy, the asset variable in the test showed a significant effect on the relationship between business strategy and MCS on the financial performance of the hotel industry in Bali. Assets are an important factor for hotels to strive to realize the company's objectives from the aspect of financial performance that focuses on hotel employees and guests. The type of analyzer strategy in the use of assets is very careful in facing dynamics, innovation and industrial competition so that it does not have an effect on the use of assets. Based on the star classification on testing shows insignificant results, meaning that the star classification has not yet fully become a factor considered in influencing the relationship of business strategy and MCS in the company to the measurement of financial performance in hotels.

Based on the results of research that the hotel can make a choice of business strategies in accordance with the vision and mission of the hotel that is implemented on strategies which are in accordance with the conditions of competition between hotels to provide financial benefits for hotels. The significance of the asset factor as a control variable in the test results also shows that the asset has a very decisive role in the direction and policy of the hotel in choosing its business strategy. it is clear that assets are capital for hotels to develop, operate and have good financial performance. Table 5 shows the results of business strategy misfit regression with MCS on nonfinancial performance.

Tabel 5. Misfit Regression

Non Financial Performance $=\lambda 0+\lambda 1|\varepsilon i|+\lambda 2$ Asset $+\lambda 3$ Star Classification

\begin{tabular}{lc}
\hline Description & Coefficient \\
\hline Intercept & $9.763^{* *}$ \\
Misfit & $-0.342^{* *}$ \\
Asset & $5.068^{* *}$ \\
Star & -0.088 \\
Adjusted $R^{2}$ & 0.23 \\
$\mathrm{~N}$ & 181
\end{tabular}

$\overline{\text { Data source results from SPSS processing } 2019}$

Based on table 5 above shows that the misfit variable is negative and significant, meaning that there is a misfit of business strategies for both defenders, prospectors and analyzers and MCS has a negative effect on financial performance at a significance of 0.05 . The satisfaction that occurs between the business strategy and MCS proves that it will affect the hotel non-financial performance. Thus the results of these tests support the $\mathrm{H} 2$ hypothesis of this study. This shows that any form of business strategy choices in the hotels will be related to MCS so that it will affect the company's non-financial performance. In this case the misfit approach in this study proves that a mismatch between business strategy and MCS will negatively affect non-financial performance, meaning that the form of business strategy and MCS conformity is absolutely essential to determine better non-financial performance. The very low adjusted $r$ square value is due to the effect of analysis of the residual value which is absolute from the misfit of business strategy and MCS. In addition there are other factors that may further affect non financial performance

These results are in line with research by Gani and Jermias (2012). As in the analysis of $\mathrm{H} 2$ test results, the choice of the defender and prospector strategies that the asset variable in the test also showed a significant effect on the relationship between business strategy and MCS in the hotel industry in Bali. Whereas the type of analyzer strategy that focuses on the principle of prudence so that the use of company assets has not been fully used as a consideration for the hotel in pursuing innovation and business activity in the face of industrial competition. For defenders 
and prospectors, assets are an important factor for hotels to strive to realize the company's goals from the aspect of non-financial performance that focuses on hotel employees and guests in pursuing innovation and facing industry competition. Based on the star classification on testing showed insignificant results, it means that the star classification has not fully become a factor considered in influencing the relationship of business strategy and MCS in the company to the measurement of non-financial performance in hotels.

Based on the results of the study that the hotel can make a choice of business strategies in accordance with the vision and mission of the hotel implemented on which strategies are in accordance with the conditions of competition between hotels to provide non-financial benefits for hotels based on hotel guest factors, staff and internal hotel business processes. The significance of the asset factor as a control variable in the test results also shows that the asset has a very decisive role in the direction and policy of the hotel in choosing its business strategy. it is clear that assets are capital for hotels to develop, operate and have an impact on good non-financial performance.

\section{CONCLUSIONS}

This study aims to provide empirical evidence about the influence of business strategic misfit with MCS negatively affecting financial performance and non-financial performance in the hotel industry in Bali. The results showed that in accordance with the hypothesis in the study that there was an influence of business strategic misfit with MCS negatively affecting financial performance and non-financial performance in the hotel industry in Bali.

In line with previous research on testing contextual variables with a contingency approach, this study examines contingency variables in the context of incompatibility analysis to be the main theme in management accounting research as an alternative to regression testing to avoid the occurrence of classic assumptions in the research model. Research in the field of management accounting specifically for management control systems with contingency approaches in subsequent studies can consider other contingency factors that use samples of the hospitality industry or other services. the reason is that the fit between contingency factors and the accounting system (such as a management control system) will better show a context that is fit because a system will not always apply equally and appropriately between organizations.

This study only uses a sample of the hotel industry in Bali so that it has not been able to generalize the results of research when using the hotel industry in Indonesia or other types of industry. These limitations can be used as recommendations for further research in addition to using other contingency variables such as firm culture that greatly determines the design of MCS in influencing firm performance

\section{REFERENCES}

Adhi Suprobo, W. (2014). Pengaruh Sistem Pengendalian Manajemen (MCS) Terhadap Kinerja Karyawan Dengan Inovasi Sebagai Variabel Intervening Pada Usaha Mikro Kecil Menengah (UMKM) Sektor Kuliner Wilayah Banyuwangi. Artikel Ilmiah Mahasiswa 2014.

Adiputra, I. M. P., Gani, L., Rossieta, H., \& Hermawan, A. A. (2019). Pengaruh Misfit Ketidakpastian Bisnis yang Dipersepsikan dengan Levers of Control Terhadap Kinerja Perusahaan. Assets: Jurnal Akuntansi Dan Pendidikan, 8(2), 117. https://doi.org/10.25273/jap.v8i2.4435

Arjaliès, D.-L., \& Mundy, J. (2013). The use of management control systems to manage CSR strategy: A levers of control perspective. Management Accounting Research, 24, 284-300. https://doi.org/10.1016/j. mar.2013.06.003

Bambang Riyanto, L. . (2001). Alternative Approach to Examining a Contingency Model in Accounting Research: A Comparison. Jurnal Riset Akuntansi, Manajemen Ekonomi., 1(1).

Bedford, D. S. (2015). Management control systems across different modes of innovation: Implications for firm performance. Management Accounting Research, 28, 12-30. https://doi.org/10.1016/j. mar.2015.04.003

Desarbo, W. S., Anthony, C., Benedetto, D., Song, M., \& Sinha, I. (2005). Revisiting the Miles and Snow 
Strategic Framework: Uncovering Interrelationships between Strategic Types, Capabilities, Environmental Uncertainty, and Firm Performance. Source: Strategic Management Journal, 26(1), 47-74. https://doi.org/10.1002/smj.431

Desmiyawati, \& Azlina, N. (2013). No TitleHubungan strategi , ketidakpastian lingkungan terhadap kinerja: Informasi broadscope sistem akuntansi manajemen sebagai variabel intervening. Akuntansi.

Dewar, R., \& Werbel, J. (1979). Universalistic and Contingency Predictions of Employee Satisfaction and Conflict. In Source: Administrative Science Quarterly (Vol. 24, Issue 3). https://about.jstor.org/terms

Dewi, M., Lo, L., Akuntansi, J., Ekonomi, F., \& Bisnis, D. (2014). SKRIPSI PENGARUH SISTEM PENGENDALIAN MANAJEMEN TERHADAP KINERJA KEUANGAN DAN NONKEUANGAN PADA BUMN.

Drazin, R., \& Van De Ven, A. H. (1985). Alternative Forms of Fit in Contingency Theory. In Quarterly (Vol. 30, Issue 4). https://www.jstor.org/stable/2392695?seq=1\&cid=pdf-reference\#references_tab_ contents

Duncan, K.R, \& Moores, K. (1989). Residual analysis: A better methodology for contingent studies in management accounting. Journal of Management Accounting Research, 1, 89-103.

Eka Nurmala Sari, F. S. (2016). PENGARUH SISTEM PENGENDALIAN MANAJEMEN TERHADAP KINERJA KEUANGAN PEUSAHAAN PADA HOTEL BERBINTANG DI KOTA MEDAN. JRAB: Jurnal Riset Akuntansi \& Bisnis, 9(2). https://doi.org/10.30596/JRAB.V9I2.458

Fauzi, H., Hussain, M. M., \& Mahoney, L. (2011). Management Control Systems and Contextual Variables in the Hospitality Industry. Asia-Pacific Management Accounting Journal, 6(2), 63-83.

Frow, N., Marginson, D., \& Ogden, S. (n.d.). 'Continuous" budgeting: Reconciling budget flexibility with budgetary control. Accounting, Organizations and Society, 35, 444-461. https://doi.org/10.1016/j. aos.2009.10.003

Gani, L., \& Jermias, J. (2012). The Effects of Strategy-Management Control System Misfits on Firm Performance. Accounting Perspectives. https://doi.org/10.1111/j.1911-3838.2012.00038.x

Heinicke, A., Guenther, T. W., \& Widener, S. K. (2016). An examination of the relationship between the extent of a flexible culture and the levers of control system: The key role of beliefs control. Management Accounting Research, 33, 25-41. https://doi.org/10.1016/j.mar.2016.03.005

Henri, J.-F. (2006). Management control systems and strategy: A resource-based perspective. Organizations and Society, 31, 529-558. https://doi.org/10.1016/j.aos.2005.07.001

Jermias, J., \& Gani, L. (2005). Ownership structure, contingent-fit, and business-unit performance: A research model and empirical evidence B. The International Journal of Accounting, 40, 65-85. https:// doi.org/10.1016/j.intacc.2005.01.004

Martyn, P., Sweeney, B., \& Curtis, E. (n.d.). Strategy and control: 25 years of empirical use of Simons' Levers of Control framework. https://doi.org/10.1108/JAOC-03-2015-0027

Muhammad Ja’far S, L. K. (2008). Sistem Kontrol Dan Kinerja: Pendekatan Interaksi Dan Sistem Untuk Riset Kontinjensi Dalam Akuntansi Manajemen. Simposium Nasional Akuntansi, 11.

Mundy, J. (n.d.). Creating dynamic tensions through a balanced use of management control systems. https:// doi.org/10.1016/j.aos.2009.10.005

Putri, L. K. (2014a). Pengaruh Ketidakpastian Lingkungan Dan Strategi Bisnis Terhadap Kinerja Manajerial Dengan Karakteristik Sistem Akuntansi Manajemen Sebagai Variabel Intervening (Studi Empiris pada Perusahaan Jasa Perhotelan di Kota Padang dan Kota Bukittinggi). Jurnal Akuntansi, 2(2), $1-17$.

Putri, L. K. (2014b). PENGARUH KETIDAKPASTIAN LINGKUNGAN DAN STRATEGI BISNIS TERHADAP KINERJA MANAJERIAL DENGAN KARAKTERISTIK SISTEM AKUNTANSI MANAJEMEN SEBAGAI VARIABEL INTERVENING. In Jurnal Akuntansi (Vol. 2, Issue 2).

Revellino, S., \& Mouritsen, J. (2009). The Multiplicity of Controls and the Making of Innovation. European Accounting Review, 18(2).

Rossing, C. P. (2013). Tax strategy control: The case of transfer pricing tax risk management. Management Accounting Research, 24, 175-194. https://doi.org/10.1016/j.mar.2013.04.008

Sawitri, P. (2012). Interaksi Budaya Organisasi dengan Sistem Pengendalian Manajemen Terhadap Kinerja Unit Bisnis Industri Manufaktur dan Jasa. Jurnal Manajemen Dan Kewirausahaan, 13(2). https://doi. org/10.9744/jmk.13.2.151-161

Speklé, R. F., van Elten, H. J., \& Widener, S. K. (2017). Creativity and control: A paradox-Evidence from the levers of control framework. Behavioral Research in Accounting, 29(2), 73-96. https://doi. org/10.2308/bria-51759 
Tsamenyi, M., Sahadev, S., \& Shi Qiao, Z. (2011). The relationship between business strategy, management control systems and performance: Evidence from China. https://doi.org/10.1016/j.adiac.2011.05.001

Van Der Meer-Kooistra, J., \& Vosselman, E. G. J. (n.d.). Management control of inter ${ }^{\oplus}$ rm transactional relationships: the case of industrial renovation and maintenance. Retrieved January 30, 2020, from www.elsevier.com/locate/aos

Widener, S. K. (2007). An empirical analysis of the levers of control framework. Organizations and Society, 32, 757-788. https://doi.org/10.1016/j.aos.2007.01.001 